\title{
Roman Britain
}

$\mathrm{R}$ ECENT study of Roman Britain has profited on the whole more perhaps than any other branch of archæological research in Great Britain by cooperation between the national administrative body, the Office of Works, with its statutory powers, the local authority, and the local archæological society, representing expert knowledge and instructed interest. A conspicuous example of the success of such co-operation is afforded by the excavation of the Forum of Roman Leicester, of which a part, the so-called Old Jewry Wall, was handed over to the custody of the Office of Works so long ago as 1920 , but of which it became possible to ascertain the true character only after the site had been acquired by the Corporation in 1935 for public baths. Thanks to an enlightened, but economical, solution of the financial problem on the part of the authority, public and private funds were able to combine to carry out a thorough examination of the site in 1936 and 1937 under the direction of Miss Kathleen Kenyon, with the result that by a further public-spirited act on the part of the Corporation, Leicester now possesses one of the most striking and remarkable monuments of Roman Britain still surviving.

The character and history of the complex of which the Old Jewry Wall had been the only visible relic since the Middle Ages, though not completely revealed, especially in regard to some of the more interesting features, until the excavations of 1937 , was apparent in the more important essentials when the work of 1936 was brought to a close. An account of the results of the first season's work has been published by Miss Kenyon recently (Trans. Leicester Lit. Phil. Soc., 1936-37).

The earliest inhabitants of the portion of the site excavated in 1936 would appear to have been slightly Romanized Celts of the Belgic tribes; but as none of the pottery then found dated from before A.D. 40, it seemed likely that they had been attracted, whence is not known, by the legionary camp established here on the line of the Roman advance. In the following period, a town was laid out on Roman lines, some of the roads constructed passing over the pits of the first occupants. For the next fifty years or so, the houses along this road were built of wood with clay-filled walls and mainly occupied by the descendants of the original tribesmen. They were becoming gradually more Romanized. Then about A.D. 120 Leicester shared in the movement for setting up grandiose municipal buildings over Roman Britain. The area was cleared and the whole laid out as a basilica and forum in the usual Roman style and on a scale which compares with any in Britain. Though the later history is obscure, the site was undoubtedly occupied in the third and fourth centuries; but towards the close of the period, the neglected state of the roads points to the time when municipal organization was breaking down and trade and other civilized activities were failing. Thereafter, more especially with the Saxon occupation, the buildings served merely as quarries, the incorporation of the wall, which survived to modern times, in an early Saxon church probably being responsible for its preservation.
A further example of the valuable results which may accrue from such co-operation between public authorities and private bodies is afforded by recent work of the Letchworth Natural History and Antiquarian Society, for a report of which we are indebted to Mr. W. Percival Westell, honorary curator of the Letchworth Museum. The Hitchin Rural District Council in carrying out a housing scheme proposed to erect cottages partly on the site of the outer bailey of Great Wymondley Castle, near Hitchin. The scheme was approved by the Office of Works, provided that it were carried out under expert archæological supervision. This supervision was undertaken at the request of the Office of Works by the Letchworth Society. Unfortunately a drainage trench, which had yielded Romano-British pottery, had already been filled in before representatives of the Society arrived, nor could it be reopened; but a series of trenches was opened as near the line as possible. From these much interesting material was obtained. A large number of bases and sherds of Romano-British pottery was found, together with bones and teeth, tiles, nails and oyster shells. In one trench at a depth of $1 \mathrm{ft} .6 \mathrm{in}$. there was discovered a flint and rubble floor, measuring six feet in width and twenty-four feet in length, while at the southwest corner was a rubbish pit. An extension of the floor, but with much smaller flints, was found at right angles and at a depth of $2 \mathrm{ft} .6 \mathrm{in}$. This was $1 \mathrm{ft} .6$ in. below the old turf level, which was plainly visible at a depth of $1 \mathrm{ft}$. below the present surface. In another trench was a circular layer of flints, within which was a rammed floor. This was without flints, and overlying it were many pieces of fired daub and cut pieces of wattle of elm wood. This would appear to be the site of a primitive oval thatched hut, probably for storage, and, it may be, pre-Roman. No pottery or other objects were found within the circle. The diameter of the circle of flints is $8 \mathrm{ft}$. The pottery found is of the first and second centuries A.D. and consists of coarse ware cooking pots, grey ware bowls, dishes and vases, and black ware. A few fragments only of Samian ware were found.

The activities of the Society in other parts of Hertfordshire have produced some interesting finds. At Baldock, an exceptionally rich region, two full. length skeletons, a quantity of pottery and building materials, as well as parts of British and Roman querns have been found. From South Road came a perfect large coarse ware brown urn, containing a heavy cremation with a Samian dish clamped at the side. This rested on the skeleton of a horse, and was found at a depth of three feet. A number of RomanoBritish finds are also recorded from Ashwell, Hitchin and Letchworth itself. The last named, the remains of four Romano-British pottery vessels, indicate that the rectangular pit-dwellings, such as recently were recorded at Haw thorn Hill, Letchworth, extended still farther to the north-west.

The excavation of the hill-fort known as The Caburn, near Lewes, which was described by Dr. A. E. Wilson before the Society of Antiquaries of London on February 10, was especially interesting for the evidence which it furnished of successive 
occupations. Pottery found in the old turf beneath the early rampart pointed to an occupation of an undefended village settlement dating at about 500 в.c. Then at about 250 B.c. the top of the hill was enclosed by a single rampart and ditch which are still visible as an inner work. At about 50 в.c. an extensive and ambitious scheme of refortification was undertaken, which included an outer rampart and ditch. This, however, seems not to have been completed. A complete rebuilding took place in the year, approximately, A.D. 50, when a full outer rampart and ditch were constructed. The site was then neglected for a thousand years, until in the eleventh century some refortification took place. The excavations have been carried out by Dr. Wilson on behalf of the Brighton and Hove Archæological Society, with the assistance of Dr. Cecil Curwen and Mr. G. P. Burstow.

An account with photographs of the recently discovered western postern for pedestrians of the
Newport Arch at Lincoln is given by Mr. F. T. Baker in Discovery of February. This arch, famous for having been in uninterrupted use since its erection probably in the second century A.D., was the northern gateway of the Roman occupation. The surviving portion consists of the southern face of the main arch and an eastern postern; but the demolition last autumn of a building abutting on the western side of the arch brought to light the spring of an arch, which confirmed previous conjecture that there had also been a postern for pedestrians on the western side. It is evident that barrack rooms, or chambers for some such purpose surmounted the arch. The discovery of a portion of the Roman city wall in the course of the work indicates that this met the structure of the gate at approximately the centre, and not flush with the south or north face as previously thought. The exterior angle, possibly, may have been filled by a bastion.

\section{The Rockefeller Foundation*}

\section{Barriers to International Aims}

$\mathrm{F}$ ROM the beginning of its activities twenty-five years ago the Rockefeller Foundation has been guided by the objective written into its charter : "The wellbeing of mankind throughout the world". In accordance with this purpose the aim of the trustees has been to maintain the work of the Foundation on an international plane without consideration of flags or political doctrines or creeds or sects. Particularly in a programme based on the advancement of knowledge it is imperative to disregard the geographical boundaries which arbitrarily and often unhappily divide the earth into a patchwork of senseless antagonisms. For in the last analysis knowledge cannot be nationalized. No successful embargoes can be maintained against the export or import of ideas. Whether new conceptions in atomic physics come from Copenhagen or from Cambridge, England; whether the cure for cancer is developed in New Haven or in Berlin; whether it is a Russian or an Italian or an American who takes the next step forward in mankind's struggle with virus diseases-we are all of us, under whatever flag, the joint beneficiaries of the intellectual property of the race. In all the clash of competing nationalisms there is here an underlying principle of unity : the single aim and language of science in the discovery of truth. It is this principle which challenges the twentieth century with the conception of civilization as a co-operative achievement and with the ideal of intellectual capital as an international possession.

A foundation, therefore, whose aim is to assist in pushing out the boundaries of knowledge must necessarily work wherever the best tools are to be found. In its search for high talent and promising opportunities it must assume that frontiers are not the forbidding barriers they pretend to be.

This ideal, which for more than two decades the Rockefeller Foundation has consistently attempted to follow, has in recent years encountered serious difficulties. And these difficulties are increasing. Objective scholarship is possible only where thought

* From the Rockefeller Foundation: A Review for 1937. By Raymond B. Fosdick, President of the Foundation. (New York, 1938.) is free-and freedom can exist only where there is tolerance, only where there are no "Keep Out" signs against the inquisitive and questioning mind. Disinterested research cannot survive in an atmosphere of compulsion and repression. It withers under the efforts of Governments to impose uniform ideologies and to circumscribe in the interests of a dominant regime the area of intellectual liberty. Particularly in the broad range of subjects covered by the social sciences, and in the humanities as well, the world has recently witnessed in several countries the progressive disintegration of creative scholarship.

This phenomenon has naturally affected the programme of the Foundation. In some fields it is now profitless to go where we formerly went. We find ourselves stopped at some frontiers-not because the frontiers have any greater geographical significance than they had a few years ago, but because behind them the search for truth by eager and sceptical minds has been made impossible.

Some twenty years ago in a Central American city a revolution developed while the Foundation was engaged in a study of yellow fever control measures. Dr. Emmett Vaughn, who was in charge of the work, determined to continue his research. Every morning with a flag of truce he crawled through the barricades to collect his mosquitos on one side of the fighting line, and in the afternoon he crawled back again to gather up his specimens on the other side. He was molested by neither army. Both sides thought him somewhat crazy - a man who, when great issues of human destiny were being fought out, spent his time catching mosquitos. To-day in that Central American country the revolution has been largely forgotten, but Dr. Vaughn is remembered as the man who helped to stamp out an age-long pestilence.

The Rockefeller Foundations likes to think of this incident as an example of what its approach to the welfare of mankind should be. But occasionally aggressive action by the fighting lines makes impossible even the gathering of mosquitos ! 